\title{
Contexts as The Determining Roles of Javanese Phatic 'Monggo': Culture-Specific Pragmatics Perspective
}

\author{
Kunjana Rahardi ${ }^{\mathbf{a}, 1}$
}

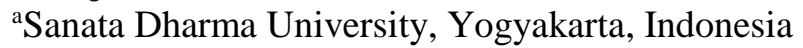

${ }^{1}$ kunjana@usd.ac.id

\begin{tabular}{ll}
\hline Article info & A B S R A C T \\
\hline Article history: & Context is a very important aspect to determine speech \\
Revised : 29-09-2019 & intentions. Failure to describe contexts potentially causes \\
Accepted: 10-10-2019 & misunderstanding. In a Javanese society, there is a phatic \\
& communion 'monggo' which has varied pragmatic meanings \\
& depending on contexts. The variety of meanings poses a potential \\
& problem for language learners. Considering this, a research is \\
conducted to investigate how contexts become determining \\
factors of pragmatic meanings of 'monggo. The research data \\
are excerpts of utterances containing phatic 'monggo'. The data \\
sources are the excerpts of utterance between the speaker and \\
hearer having Javanese cultural backgrounds. The data are \\
gathered using the observation method, by recording and note- \\
taking as the basic and advanced techniques. The gathered data \\
are classified carefully to be analyzed using the contextual \\
identity analysis method. The research result shows the roles of \\
contexts as follows: (a) determine the phatic meaning of \\
'monggo', (b) provide a background of the phatic meaning of \\
'monggo', (c) confirm the phatic meaning of 'monggo', and (d) \\
describe the phatic meaning of 'monggo. The pragmatic \\
meanings of the phatic 'monggo' include: (a) inviting sincerely, \\
(b) inviting hesitantly, (c) prohibition, (d) doubt, (e) excuse me, \\
and (f) invitation.
\end{tabular}

Keywords:

culture-specific determining roles doubt phatic 'monggo' pragmatic
Konteks sangat penting dalam menentukan maksud pembicaraan. Kegagalan untuk menggambarkan konteks berpotensi menyebabkan kesalahpahaman. Dalam masyarakat Jawa, ada kata 'monggo' yang memiliki beragam makna pragmatis tergantung pada konteksnya. Keragaman makna menimbulkan masalah bagi pemelajar bahasa. Berdasarkan hal tersebut, penelitian ini dilakukan untuk menyelidiki konteks yang menjadi faktor penentu terhadap makna pragmatis dari 'monggo'. Data penelitian adalah kutipan dari ujaran yang mengandung kata 'monggo'. Sumber data adalah kutipan dari ujaran antara pembicara dan pendengar yang memiliki latar belakang budaya Jawa. Data dikumpulkan dengan menggunakan metode observasi, dengan mencatat yang juga digunakan sebagai teknik dasar dan lanjutan. Data yang terkumpul diklasifikasikan dengan cermat untuk dianalisis menggunakan metode analisis identitas kontekstual. Hasil penelitian menunjukkan peran konteks, meliputi: (a) menentukan makna kata 'monggo', (b) memberikan latar belakang makna kata 'monggo', (c) mengonfirmasi makna kata 'monggo', dan (d) menguraikan makna kata 'monggo'. Adapun arti pragmatis kata 'monggo', 
yaitu: (a) mengundang dengan tulus, (b) mengundang ragu-ragu, (c) melarang, (d) keragu-raguan, (e) permohonan maaf, dan (f) undangan.

Copyright $@ 2019$ Institut Agama Islam Negeri Syekh Nurjati Cirebon. All rights reserved.

\section{INTRODUCTION}

The study on the Javanese phatic 'monggo' from the pragmatic perspective has never been done by linguists. Meanwhile, the Javanese phatic word 'monggo' is used pervasively in the Javanese daily communication. The high frequency of use of a linguistic entity is inseparable from its role in carrying out the communicative function (Schandorf, 2013). For example, the phatic word 'monggo' is used when someone says 'monggo, tidak ada yang memakai kok' or 'Please sit down. The chair's empty.' The phatic word 'monggo' also appears in another linguistic situation, for example 'monggo saja, penjenengan bebas menentukan sebagai pimpinan' or 'Do whatever you please. You're the boss.' In the last form, the phatic word 'monggo' has a different pragmatic function from the previous utterance. In the second utterance, the pragmatic meaning of the phatic 'monggo' implies the meaning 'letting go' or 'washing hands'.

The phatic 'monggo' in the following utterance 'monggo enggal kondur sampun sonten' or 'Let's go home. It's getting late,' has a different pragmatic meaning from the phatic communion 'monggo' in the first and second utterances. In the third utterance, the meaning of the phatic communion 'monggo' is an invitation. The difference in the pragmatic meanings appearing in various utterances is caused by misunderstanding in the communication and social interaction (Mey, 2004). The potential misunderstanding must be avoided to maintain good relationships between members of the society.

This research was conducted in order to find out various possible pragmatic meanings of 'monggo' in diverse contexts of utterances. Qualified communication and interaction is necessary to establish, especially in a multicultural society like Indonesia (Rahardi, 2017d). This is an important research on the Javanese phatic communion 'monggo' to develop the Indonesian language. The Javanese language is one of the main pillars of the Indonesian language. It would be impossible for the Indonesian language to be fully developed if the linguistic phenomena containing Javanese languages had not been described thoroughly (Rahardi, 


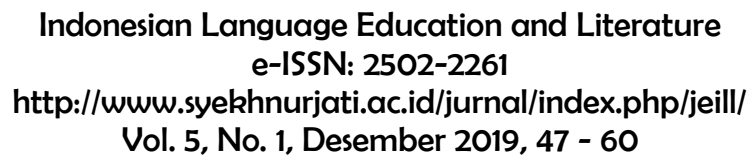

2018b). Therefore, it can be said that this research on the Javanese phatic communion 'monggo' will contribute to the development and ennoblement of the Indonesian language.

The theory of phatic communion was proposed for the first time by Malinowski (in Jumanto, 2014). Malinowski explains thoroughly the idea of phatic communion as 'to refer to this social function of language which arises in order to maintain rapport between people in line with the maxims of politeness. In other words, phatic communication is used to establish social relationships rather than impart factual information. Therefore, phatic communion is considered to be very important, such as to establish, maintain, and sustain relationship among members of society (Chen, 2017). The social function to establish the cooperation is in line with the maxim of politeness proposed by Leech. Phatic communion refers to the intention to establish social relationship instead of providing factual information (Leech, 2014).

The example is when lecturers are walking down the hallway heading to the lecture room, the one walking past the other would say 'monggo, mendahului ya' or literally 'Excuse me, I will walk past you' and the second person would say 'monggo, terus kemawon' or literally 'please, go right ahead.' In terms of phatic communion, 'monggo' in the first utterance is different from that in the second utterance. In the first utterance, the meaning of 'monggo' is 'Excuse me' while the meaning of 'monggo' is 'go ahead'. The different pragmatic meanings as shown above are inseparable from the situational context of the utterance. It means that the situational context of the utterance plays a role in determining the pragmatic meaning of utterances (Chen, 2017), (Leech, 2007).

In another reference, phatic communion is also closely related with the concept of 'ties of union.' The main purpose of phatic communion is to tie the union of among the members of the community (Jumanto, 2014). Therefore, the communion has become the main purpose of people communicating with each other using a language. Thus, communication is not the main purpose of people's use of language as described in the references by the Western experts (Rahardi, 


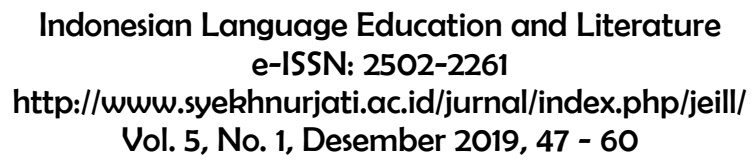

2010). Furthermore, Jakobson talks about 'phatic' as 'a channel of communication' to sustain communication (Kulkarni, 2014).

As the 'channel of communication' is built, silence as a result of the lack of communication among the people is broken. In adjacent to that, Leech calls it 'silence breaking' which is essentially an attempt to 'break the silence' (SpencerOatey \& Jiang, 2003). When the mutual silence breaks, the communication between the speaker and listener takes place.

Another theory used to be the basis for the analysis of the phatic function 'monggo' is the theory of context. The type of context described in this research is the extralinguistic context, either social, societal, cultural, or situational (Rahardi, 2015), (Joseph, 2005). Several types of context are closely connected between one and the other and they are widely used to make meaning of the utterance in the sociolinguistic, sociopragmatic, or pragmatic dimensions.

Contexts in sociolinguistics are commonly used to describe intention in relation to linguistic variations. Contexts in sociopragmatics are commonly used to describe the pragmatic meaning in relation to culture-specific domain (SpencerOatey \& Jiang, 2003). Contexts in pragmatics are widely used in relation with the utterance situations (Rahardi, 2018a). Contexts in terms of phatic function 'monggo' in this research are closely related to the three types of contexts previously mentioned. However, since the perspective used in this research is pragmatic perspective in a culture-specific domain, namely the Javanese culture, the extralinguistic context in the sociopragmatic and pragmatic dimensions is more dominantly used than the contexts in the sociolinguistic dimension, commonly referred to as social and societal contexts (Leech, 2007), (Rahardi, 2018c).

\section{METHOD}

The research aimed to find out the role of context in determining the meaning of the phatic function 'monggo' is descriptive qualitative research. The locational source of the research data is the daily utterances in the Javanese community, especially spoken by those living in Yogyakarta and around the 
researchers. Substantially, the source of the research data is the utterances spoken by the Javanese community in the location previously determined (Mahsun, 2005), containing the phatic function 'monggo' in the clearly-identified cultural and situational contexts (Rahardi, 2017c).

The research data are excerpts of utterances containing the phatic function 'monggo' in clearly-identified contexts, obtained from the bigger excerpts of utterances as the source of data. The data was gathered using the observation method, both listening and speaking method and listening and recording method. The techniques used to apply the observation method in data gathering are recording and note-taking (Sudaryanto, 2016), (Verschueren, 1997).

The collected data was then classified and categorized to be subject to the data analysis method and techniques. The data analysis method applied was the contextual identity method (Mahsun, 2005). The contextual identity method was applied because the purpose of the research was to describe the pragmatic meaning of the phatic function 'monggo' in various contexts.

\section{RESULT AND DISCUSSION}

The determining role of contexts in relation to the Javanese phatic function 'monggo' in this research can be described in the natural data such as in the following excerpts.

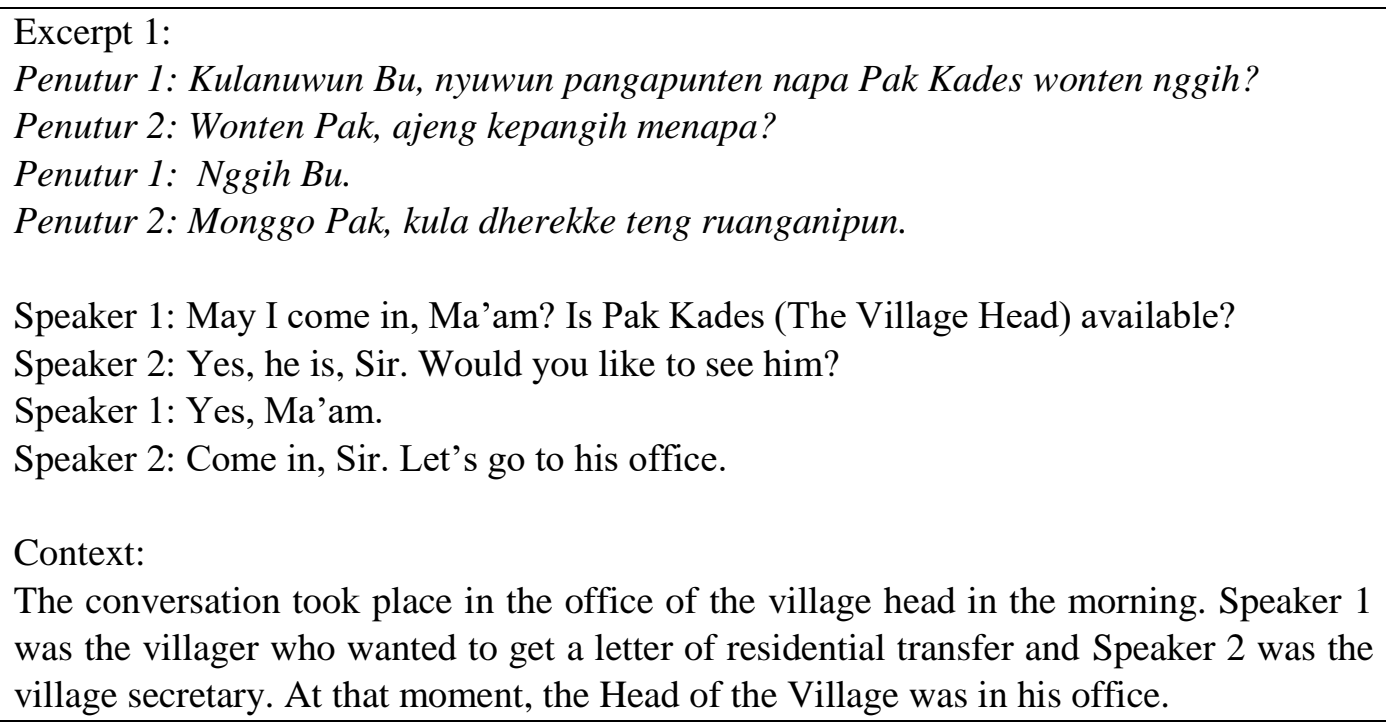


The phatic function 'monggo' in the above excerpt has a pragmatic meaning of 'invitation.' The pragmatic meaning of 'inviting' can be seen easily from the linguistic context, namely the linguistic forms following the word 'monggo, as in 'kula dherekke teng ruanganipun' or 'Let's go to his office." In addition, it can also be seen from the extra linguistic context.

The extralinguistic context of the utterance above shows that the Speaker 1 is a villager who wants to see the Head of Village to get things done. Speaker 2, the Village secretary, welcomes the guests to see the Head of Village, and takes the villager to see and sort out some administrative works with the head of the village. Therefore, it is clear that the extralinguistic context above determines the pragmatic meaning of the phatic function 'monggo', an invitation, which sets it apart from the pragmatic meaning of the other phatic function 'monggo' (Bucciarelli, 2010).

The pragmatic meaning of the word 'monggo' in Excerpt 2 has a different meaning, namely 'Well go ahead.' However, the meaning of the form 'monggo! Aku ya iso lapor Bu Guru nek tugasmu wingi mung njupuk seko internet' has a speech act of 'threatening'. Therefore, the meaning of 'go ahead' in this case contains the speech act of 'threatening.' The 'threatening' speech act used by Speaker 2 serves the function as 'prohibiting' the Speaker 1 from doing something. This intention is clearly seen from the extralinguistic context presented in the following Excerpt 2 below.

Therefore, the phatic function 'monggo' which can be interpreted in the Indonesian language as 'please' does not genuinely mean 'please'. On the contrary, the meaning of the phatic function 'monggo' means 'prohobition'. From the ortographic dimension, the phatic function 'monggo' means 'please.' The other meaning of the phatic function 'monggo' is the opposite, namely 'prohibition'. The extralinguistic context in the sociocultural and situational dimensions can be used to capture the intention of the utterance (Breeze, 2011). Furthermore, regarding the notion of pragmatics, Excerpt 2 can be examined further. 
Excerpt 2:

Penutur 1: Aku arep lapor bu Guru nek kowe mau nyonto buku pas ulangan.

Penutur 2: Monggo! Aku yo iso lapor bu Guru nek tugasmu wingi mung njupuk seko internet.

Speaker 1: I will tell the teacher that you copied from the book during the exams.

Speaker 2: Well, go ahead! I can tell her that you copied from the Internet for your assignment.

Context:

Speaker 1 and Speaker 2 are classmates. The conversation took place inside the classroom after the Social Science test was completed. Speaker 1 knew that Speaker 2 opened his book during the test. Speaker 1 did not like that Speaker 2 cheated during the exams, Speaker 2 threatened Speaker 1 who would report his misconduct to the teacher. Speaker 2 said that a few days earlier, Speaker 1 copied an article from the Internet and submitted it and claimed it as his own work.

The words 'monggo' and 'monggo, monggo' in Excerpt 3 below have different meanings. The phatic 'monggo' in the utterance 'Monggo ngunjuk Pak,' or 'Please, have a drink' is an invitation. It means that Speaker 1 really asks Speaker 2 to drink when one of them is visiting the other.

From the extralinguistic context, it is clear that the phatic 'monggo' in 'Monggo ngunjuk Pak', is really an invitation. On the contrary, the phatic 'monggo' conveyed repeatedly as in 'Monggo, monggo Pak...Disekecakkaken,' or 'Please, please, Sir. Help yourself,' means 'please.' The meaning of 'please' is conveyed seriously by Speaker 2, as the host.

The seriousness of the speaker's intention is conveyed in the form of repeated phatic 'monggo', to mean that it was more than just a small talk. Thus, it is clear that the phatic 'monggo' is far from being a small talk. In a certain context, both forms can refer to the same pragmatic meanings, but in this context of utterance, both are different (Wharton, 2009). Excerpt 3 must be examined further to clarify the point. 
Excerpt 3:

Penutur 1: Monggo ngunjuk Pak.

Penutur 2: Monggo, monggo Pak...Disekecakkaken.

Speaker 1: Please, have a drink, Sir.

Speaker 2: Please, please, Sir. Help yourself.

Context

Speaker 1 is the guest and Speaker 2 is the host. The conversation took place in Speaker 2 's living room. Speaker 1 paid a visit to discuss the meeting in the previous night about the village excursion.

The phatic 'monggo' in 'Inggih Bu, monggo pareng!' has a different pragmatic meaning from that being conveyed in the previous excerpts. The phatic 'monggo' in this excerpt means 'excuse me' as a form of 'good bye' because the speaker will leave the place. The pragmatic meaning of 'excuse me' shows politeness in speech and behavior.

In the Javanese culture in general, speech politeness is shown not only through linguistic forms but also through non-verbal dimensions following the utterance. As one is leaving the place, someone will say 'monggo' or 'excuse me' while bowing their body $45^{\circ}$ and walking more briskly than usual. Thus, it can be concluded that phatic 'monggo' is closely related with linguistic politeness. It can even be said that the phatic forms in certain contexts are the manifestation of linguistic politeness (Rashid, Ismail, Ismail, \& Mamat, 2017), (Leech, 2014). Excerpt 4 can be examined further to capture the meaning of the phatic function related to politeness.

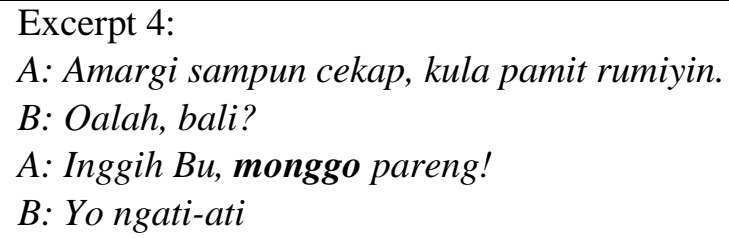

A: That's all I have to say. Now, I'd like to say goodbye.

B: Really? Do you want to go home?

A: Yes, Ma'am, if you will excuse me. Bye!

B: Alright. Take care.

Context:

A is a student. B is a teacher. The conversation took place when A paid a visit in B's home. A is much younger than B. At the end of the meeting, A said good bye to B. Monggo in this situation is understood as 'if you will excuse me.' 


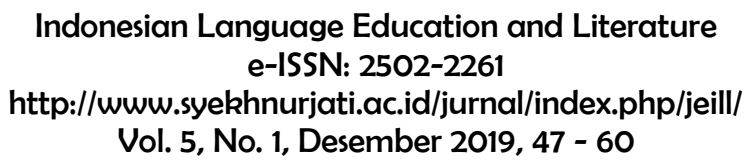

The phatic form 'monggo' in 'Yo monggo nek koe wani!' or 'Well, go ahead if you can do it yourself' has a pragmatic meaning of 'letting other people to do it' with a hint of 'doubt'. In other words, the pragmatic meaning appears in the linguistic form is not 'letting others to do it' but it actually means 'prohibition' (Leech, 2007). The doubt being conveyed by the speakers is actually meant to 'prohibit' the hearer from doing something, in this case 'asking the signature from the Vice Rector of Financial Affairs.' The extralinguistic context following the utterance can be examined further as to why the pragmatic meaning of 'prohibition' appears in the phatic 'monggo'.

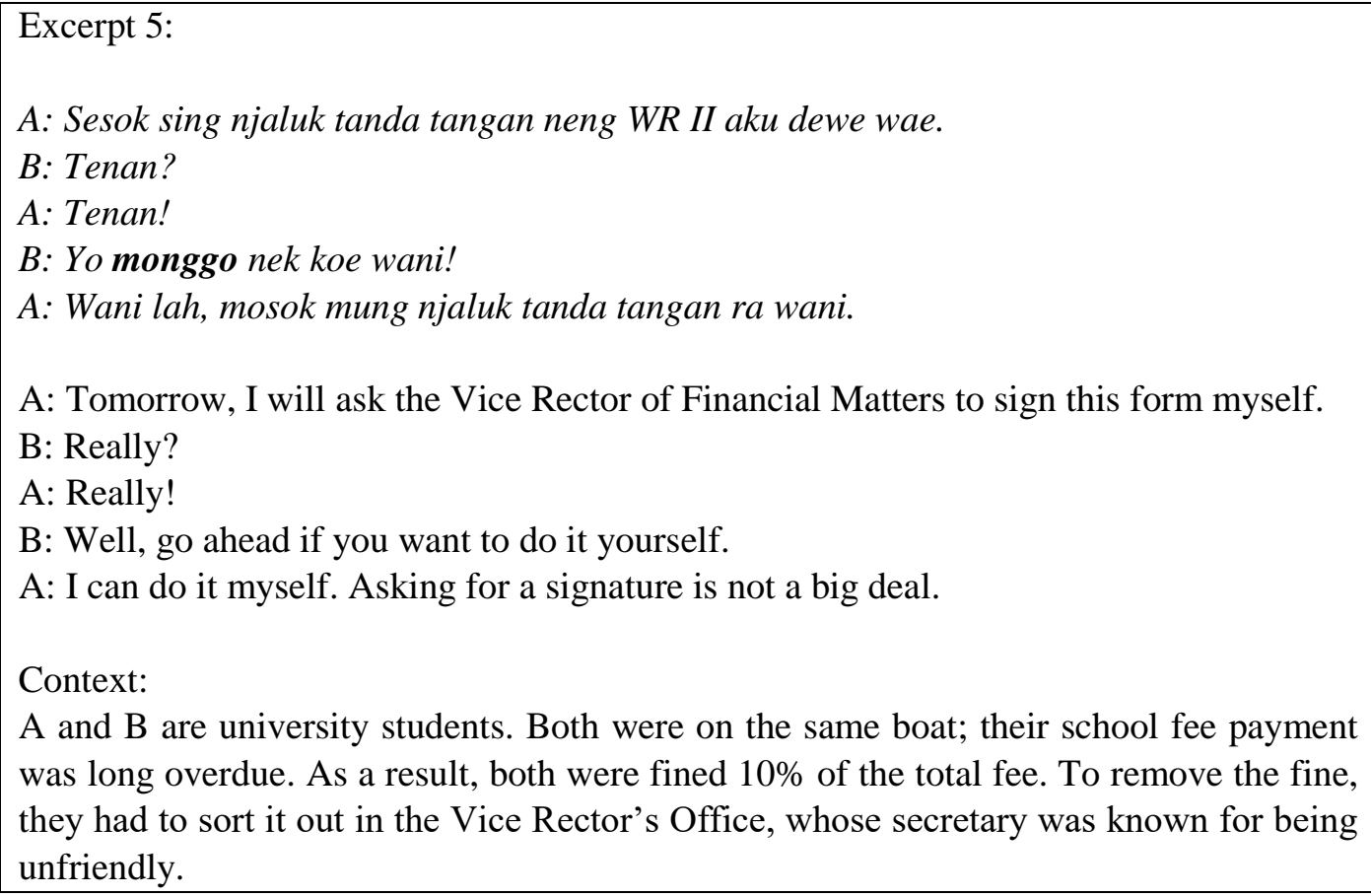
was long overdue. As a result, both were fined $10 \%$ of the total fee. To remove the fine, they had to sort it out in the Vice Rector's Office, whose secretary was known for being unfriendly.

The phatic 'nggo' is short for 'monggo'. In a daily conversation, the restricted codes as in the utterance 'Nggo Bu, sekalian mawon pripun?' are often found. In the excerpt, the word 'nggo' or 'monggo' has a pragmatic meaning of 'offering.' It means that the speaker offers to the hearer to go home together. The form 'sekalian mawon' or 'why don't you ride with me' means that the speaker offers the hearer a ride on his motorcycle or car. The form 'monggo' being used could mean a real offer. However, oftentimes the form 'monggo' could be a small talk or pretentious politeness (Suszczyńska, 2011). 
A certain expert calls it fake politeness because what is conveyed is different from what is meant (Rahardi, 2017b). Whether the utterance 'monggo' can be interpreted as an invitation or whether it has another pragmatic meaning, the determining factor is the context. Therefore, it can be confirmed that context plays a very important role in determining the intention and the pragmatic meaning of the utterance. The following excerpt 5 can be examined further to confirm the existence of the pragmatic meaning.

\section{Excerpt 6:}

A: Dereng dijemput Bu?

B: Iki mau ngebel anakku neng kok ra tenak-tekan

A: Nggo Bu, sekalian mawon pripun?

A: You're still here, Ma'am. No one to pick you up?

B: I have called my son for many times, but the line cannot get through.

A: Well, if you want, why don't you ride with me?

Context:

$\mathrm{A}$ and $\mathrm{B}$ are teachers teaching at the same school. The conversation took place in the school gate after school hours. A was riding a motorcycle ready to go home. At the gate, A saw B (his co-worker) looking worried while waiting for her son to pick her up. Out of compassion and care, A offered B a ride home. The word 'monggo' in this context is used to mean offering / giving an offer.

The phatic form 'monggo' in the utterance 'Woalah..., monggo pinarak rumiyin' or 'Well, please, why don't you just come in over?' can be understood pragmatically as an 'invitation.' It refers to the invitation from the speaker to the hearer to come over after supervising the rice field. The Javanese people often say that this form is a speech act of 'inviting', while the hearer uses the expression to imply 'being invited to.' The communicative activity often uses the phatic 'monggo.' Close observation of the context will reveal whether a speaker really intends to 'invite' or he or she just pretends to 'invite'. The concept of 'inviting' and 'being invited to' is closely related with the socializing term 'grapyak' or 'gregarious' because usually people who often invite their friends or relatives are said to have the trait of 'grapyak' or 'gregarious'.

Other sources mention this kind of character as 'semanak' or 'friendly'. Both phatic forms can be combined to form the expression 'grapyak-semanak', or 
being socially friendly, a character which is typically Javanese (Rahardi, 2017a). Close observation to Excerpt 7 will help readers to understand whether the speaker really 'invites' or 'gets friendly' with the hearer', or he 'pretends to be friendly' as conveyed in the previous analysis of the utterance.

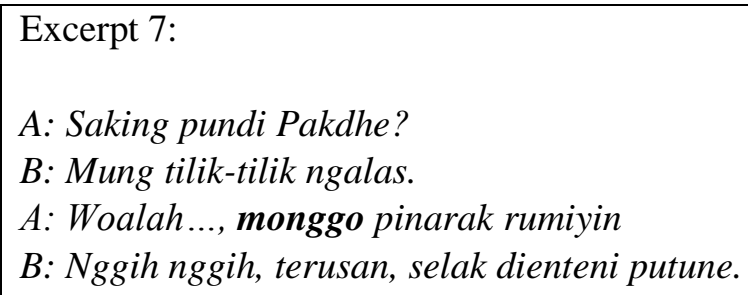
saw B pass by her house. To break the ice and to establish good relationship, A accosted B. When B responded, A started a small talk by offering B to come over her house for a little while. Actually A did not really mean to invite B to come over her house.

\section{CONCLUSION}

After a careful analysis of the data, some conclusions can be drawn. It can be confirmed that the pragmatic meaning of the phatic 'monggo' can be more various than those found in this article. Various contexts will provide various pragmatic meaning of 'monggo'.

This simple research has succeeded in finding various pragmatic meanings of the phatic 'monggo', namely (1) the pragmatic meaning of 'inviting sincerely,' (2) the pragmatic meaning of 'inviting hesitantly', (3) the pragmatic meaning of 'prohibition,' (4) the pragmatic meaning of 'doubt,' (5) the pragmatic meaning of 'excuse me', (6) the pragmatic meaning of 'invitation.' The findings of the pragmatic meanings above are very important to initiate bigger research on the pragmatic meaning of the phatic 'monggo' to find out more extensive pragmatic meanings.

The various pragmatic meanings of 'monggo' are not separated from the existence of linguistic and extralinguistic contexts. However, it is the 
extralinguistic context that plays a determining factor to the intention or pragmatic meaning. The roles of pragmatic contexts found in this research, namely: (a) determine the phatic meaning of 'monggo', (b) provide a background of the phatic meaning of 'monggo', (c) confirm the phatic meaning of 'monggo', and (d) describe the phatic meaning of 'monggo.'

\section{ACKNOWLEDGEMENTS}

The author expressed his gratitude to DRPM KEMRISTEKDIKTI who has given research grants consecutively for more than six years.

\section{REFERENCES}

Breeze, R. (2011). Critical discourse analysis and its critics. Pragmatics 21(4), 493 - 525. DOI: https://doi.org/10.1075/prag.21.4.01bre.

Bucciarelli, M. (2010). Proffering a discourse in different communicative contexts. Journal of Pragmatics, 42(5), 1311 - 1320. DOI: https://doi.org/10.1016/j.pragma.2009.09.024

Chen, J. (2017). Research Trends in Intercultural Pragmatics. Australian Journal of Linguistics, 37(2). DOI: https://doi.org/10.1080/07268602.2016.1204903

Joseph, C. A. B. (2005). Language in contact and literatures in conflict: Text, context, and pedagogy. World Englishes, 24(2), 131 - 143. DOI: https://doi.org/10.1111/j.1467-971X.2005.00398.x

Jumanto. (2014). Phatic Communication: How English Native Speakers Create Ties of Union. American Journal of Linguistics, 3(1), 9 - 16. DOI: https://doi.org/10.5923/j.linguistics.20140301.02

Kulkarni, D. (2014). Exploring Jakobson's "phatic function" in instant messaging interactions. Discourse and Communication, 8(2). DOI: https://doi.org/10.1177/1750481313507150

Leech, G. (2007). Politeness: Is there an East-West divide? Journal of Politeness Research. DOI: https://doi.org/10.1515/PR.2007.009

Leech, G. (2014). The Pragmatics of Politeness. The Pragmatics of Politeness. DOI: https://doi.org/10.1093/acprof:oso/9780195341386.001.0001

Mahsun, M. (2005). Metode Penelitian Bahasa. Jakarta: PT Raja Grafindo Persada. 
Mey, J. L. (2004). Pragmatics: An Introduction. Pragmatics.

Rahardi, R. K. (2010). Sosiopragmatik (1st ed.). Jakarta: Erlangga.

Rahardi, R. K. (2015). Menemukan Hakikat Konteks Pragmatik. Prosiding Seminar PRASASTI.

Rahardi, R. K. (2017a). Kefatisan Berbahasa: Kajian pragmatik tutursapa keseharian warga masyarakat. In KOLITA 15, 7 - 11. Jakarta: Atmajaya Catholic University.

Rahardi, R. K. (2017b). Language Phatic in Specific Culture Perspective. In 1st International Conference on Education, Language, and Arts, 1165 - 1174. Jakarta: Universitas Negeri Jakarta.

Rahardi, R. K. (2017c). Linguistic Impoliteness in The Sociopragmatic Perspective. Jurnal Humaniora, 29(3), 309 - 315. DOI: https://doi.org/10.22146/jh.v29i3.24954.

Rahardi, R. K. (2017d). Pragmatic Phenomena Constellation in Specific Culture Dimension Language Study. International Journal of Humanity Studies, 1(1), 84 - 92. DOI: https://doi.org/doi.org/10.24071/ijhs.2017.010109.

Rahardi, R. K. (2018a). Elemen dan Fungsi Konteks Sosial, Sosietal, dan Situasional dalam Menentukan Makna Pragmatik Kefatisan Berbahasa. In Prosiding Seminar Tahunan Linguistik Universitas Pendidikan Indonesia (SETALI 2018), 654 - 658. Bandung: Sekolah Pascasarjana Universitas Pendidikan Bandung.

Rahardi, R. K. (2018b). Konstelasi Kefatisan dalam Teks-teks Natural Religius dengan Latar Belakang Kultur Spesifik. In Prosiding Kongres Internasional Masyarakat Linguistik Indonesia 2018, 274 - 279. Manokwari, Papua Barat: MLI.

Rahardi, R. K. (2018c). Pragmatik: Kefatisan berbahasa sebagai fenomena pragmatik baru dalam perspektif sosiokultural dan situasional (1st ed.). Jakarta: Erlangga.

Rashid, R. A., Ismail, I. R., Ismail, R., \& Mamat, R. (2017). Ketidaksantunan dalam Perbualan Bahasa Jepun oleh Pemandu Pelancong Malaysia. GEMA Online Journal of Language Studies, 17(3), 86 - 105. DOI: https://doi.org/10.17576/gema-2017-1703-06

Schandorf, M. (2013). Mediated gesture: Paralinguistic communication and phatic text. In Convergence, 19(3). DOI: https://doi.org/10.1177/1354856512439501 
Spencer-Oatey, H., \& Jiang, W. (2003). Explaining cross-cultural pragmatic findings: Moving from politeness maxims to sociopragmatic interactional principles (SIPs). Journal of Pragmatics, 35(10-11), 1633 - 1650. DOI: https://doi.org/10.1016/S0378-2166(03)00025-0

Sudaryanto. (2016). Metode dan Aneka Teknik Analisis Bahasa (1st ed.). Yogyakarta: Sanata Dharma University Press.

Suszczyńska, M. (2011). Pragmatics across Languages and Cultures. Journal of $\begin{array}{llll}\text { Pragmatics, } & 43(11), & 2872 \quad- & 2875 .\end{array}$ https://doi.org/10.1016/j.pragma.2011.04.004

Verschueren, J. (1997). Meaning in Interaction: An Introduction to Pragmatics. Pragmatics, 28(2), 253 - 261. DOI: https://doi.org/10.1016/S03782166(97)84203-8

Wharton, T. (2009). Pragmatics and non-verbal communication. Pragmatics and Non-Verbal Communication. https://doi.org/10.1017/CBO9780511635649 